\title{
Self-regulating roof-bolting with the rock pressure energy use
}

\author{
Oleh Khomenko ${ }^{1 *}$, Maksym Kononenko ${ }^{1}$, Ihor Kovalenko ${ }^{2}$, and Denys Astafiev ${ }^{1}$ \\ ${ }^{1}$ National Mining University, Department of Underground Mining, 19 Yavornytskoho Ave., \\ 49005 Dnipro, Ukraine \\ ${ }^{2}$ Ukrainian State Chemical Technology University, Inorganic Chemistry Department, 8 Haharina \\ Ave., 49000 Dnipro, Ukraine
}

\begin{abstract}
The perspective of discovery of zonal disintegration phenomenon of rocks around underground mine workings is analyzed. The methodological stages for research of this phenomenon are shown. The physics of zonal disintegration of rocks around underground mine workings is disclosed. There are described the possibilities of advanced entropy method and developed energy method that allow to investigate a phenomenon of zonal capsulation of underground mine workings. The sequence of research of this phenomenon parameters is presented. The order of choice of stable shape and resource-saving support in underground mine workings is substantiated, for the deep horizons of the Kryvorizkyi Iron-Ore Basin mines. The method of parameters calculation of selfregulating roof-bolting in underground mine workings is substantiated, which allows to use the rock pressure energy. The design of a selfregulating roof-bolting is developed, which allows applying metal, polymer and rope bolts. The economic efficiency of rock pressure energy usage is substantiated in case of support setting at great depths in underground mine workings.
\end{abstract}

\section{Introduction}

The problem of physics disclosure of phenomenon of zonal disintegration of rocks around mine workings, which first was discovered in 1972 in the South African mine and then in the USSR, Russia, Ukraine, Kazakhstan, the USA, Japan and other countries of the world, for a long time could not find a solution [1 - 3]. The discovery of the phenomenon itself has given only a comprehension about formation of the self-organized circular-type structures around underground mine workings. The first hypotheses rejected the physical reality of the discovery, but since the 1990s, the new methods which also did not describe the mechanisms for the energy zones formation, have been actively used in mining science [4]. Therefore, this phenomenon has been recognized as one of the most difficult problems in mining science, and cannot be described on the basis of the classical laws of physics and geomechanics. At the very stage of a scientific problem analysis, with the use of synergetic methodological search, we have managed to disclose the physics of the studied phenomenon and called it as zonal

\footnotetext{
* Corresponding author: rudana.in.ua@gmail.com
} 
capsulation of mine working using a system of annular energy zones [5, 6].

Then, by means of the improved entropy method, the virgin massif state has been modeled. It was established that the processes of energy exchange in rocks proceed in mutually perpendicular directions corresponding to vertical and horizontal energy flows. It made possible to describe the processes, to determine the parameters and to establish the patterns of potential energy redistribution in rocks of the Ukrainian crystalline shield [7, 8]. Then, by means of the developed energy method, the parameters of mine workings capsulation were investigated using the 'convergence' and 'divergence' categories, which are phases of the centripetal self-organization of open systems. As a result of the convergence, the rock massif containing mine working is divided into integration subzones, and at divergence disintegration subzones [9]. Due to the convergence and divergence, the massif resists to mining operations in it and restores the continuity, forming the protective capsule, which consists of the energy zones system [10]. The conducted research of a zonal capsulation phenomenon of mine workings with the help of new methods have made it possible to establish the exact quantity, the sizes and a shape of energy zones, and, most importantly to reveal the sinusoidal stresses and annular areas of deformation [11]. It is established that the energy of the safety capsule, formed around the mine working, can be used according to parabolic-and-hyperbolic dependence, the values on which correspond to the reasonable principles: resistance, equilibration, facilitating, elimination and transmission of concentrated energy of the massif on which the proposed technology solutions are based [12].

\section{Methods}

The prospect of Kryvorizkyi Iron-Ore Basin development on mining of thick steep deposits in the range of $1500-3000 \mathrm{~m}$ depths is connected with application of high-performance self-propelled and, accordingly, the large-sized drilling and loading transport equipment [13]. Ensuring the preparatory mine workings stability with a cross-section area up to 20sq.m and above is rational with the use of a stable shape. But, with an increase in depth to more than $1000 \mathrm{~m}$, it is reasonable already to set the self-regulating roof-bolting with the use of the rock pressure energy [14].

The calculated values of a shape coefficient of energy zones $\lambda$ entering the safety capsule of the mine working are defined as the ratio of vertical potential stress to horizontal one $\left(\lambda=\Delta \sigma_{z(y)} / \Delta \sigma_{x(y)}\right)$, and are represented in the form of multiple exponential functions in Fig. 1.

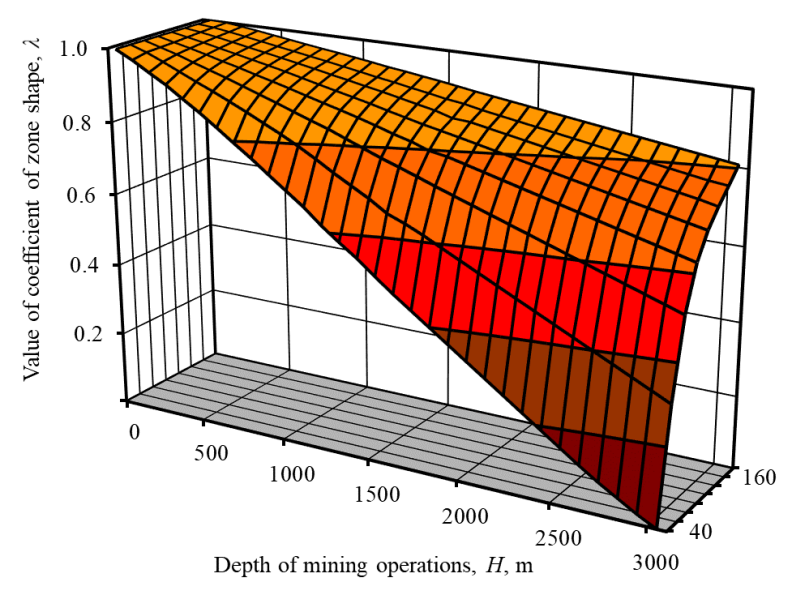

Fig. 1. Values of $\lambda$ for various depth of mining operations and strength of Kryvbas rocks. 
With the use of $\lambda$ coefficient, the sizes of the vertical $a$ and horizontal $b$ semi-axes of the energy zone bordering on the mine working are determined as, $\mathrm{m}$

$$
a=0.5\left(d \lambda^{-1}+h\right) ; b=a \lambda
$$

where $d$ is the width and $h$ is the height of preparatory mine working, m [15].

When calculating a stable contour of mine working, the minimum value $\lambda$ is accepted as equal to 0.5 . If $\lambda<0.5$, then the rock pressure on the support increases significantly. In this case, the rock swelling is possible, and this forces to form a complete ellipsoid with the outcrop of massif and to fasten it with pliable metal sets, framed through $0.2-0.5 \mathrm{~m}$, or with monolithic concrete. The results of modeling the stable shape of a mine working and application of the traditional for ore mines and new way of support setting, innovative selfregulating roof-bolting, are set out in Table 1 [16].

Table 1. The stable cross-sectional shape and resource-saving type of support setting in the preparatory mine working, constructed in rocks with a strength of $80 \mathrm{MPa}$.

\begin{tabular}{|l|c|c|c|c|c|}
\hline $\begin{array}{c}\text { Laying depth of } \\
\text { mine working, } \mathrm{m}\end{array}$ & 350 & 700 & 1000 & 1600 & 3000 \\
\hline Value $\lambda$ & $1.0-0.9$ & $0.9-0.8$ & $0.8-0.7$ & $0.7-0.5$ & $0.5-0.1$ \\
\hline \multicolumn{6}{|c|}{ Traditional shape and support } \\
\hline Shape & trapezium-shaped & $\begin{array}{c}\text { arched } \\
\text { wooden }\end{array}$ & $\begin{array}{c}\text { reduced-weight } \\
\text { arched }\end{array}$ & improved arched & $\begin{array}{c}\text { monolithic } \\
\text { concrete }\end{array}$ \\
\hline Support & \multicolumn{7}{|c|}{ Resource-saving shape and support } \\
\hline Shape & circular & arched & crescent-shaped & semielliptical & elliptical \\
\hline Support & $\begin{array}{l}\text { without } \\
\text { support }\end{array}$ & shotcrete & bolting & reduced-weight combined \\
\hline
\end{tabular}

The proposed approach to the choice of the new type of support is implemented according to the principle of resistance of support to the pressure of enclosing rocks. In other words, with an increase in depth of mine working laying, there is an increase in the volume of rocks, which must be supported $[17,18]$. Partially, it is possible to lower the loading (up to $10 \%$ ) by means of giving a stable contour to the outcrop of massif, and the rest part of loading is supported by setting the support itself. The higher the loading value, the more complex and expensive the constructions of applied supports. Until now, the complexity of mining-and-technical conditions caused an adequate support structure modification only for the purpose of minimizing costs. The problem of using the energy of triaxial compression of rocks as the main resource of efficiency increasing in the mine workings operation, the quality of setting and maintenance their support has been solved only in recent years [19].

Due to a system research of the phenomenon of zonal capsulation of mine workings, an analytical description of a pattern of self-organization of the massif disturbed by the mine working, the possibility is opened of using a new principle in the technology of support setting and maintenance of mine workings. The innovative principle practically excludes the influence of depth in mine workings drivage on the prime cost of their support setting $[20,21]$. Its essence consists in that the most part of loading on the support, created by the pressure of the underworked thickness (convergence), is counterbalanced by the loading from the divergence processes development by means of application of self-regulating roofbolts as a part of the combined support. The possible depths of the proposed technological solution application are closely connected with the process of zonal capsulation, i.e. formation of the second and the subsequent energy zones around mine workings. Based on 
the research results, the authors have developed a method for calculating the support setting passport of preparatory mine workings which uses the rock pressure energy [22].

1. Roof-bolts length:

- for a roof and a bottom of mine working at the small radius of contour corners, $\mathrm{m}$

$$
l_{a}=2 a-r+l_{n}
$$

- for mine working sides at the large radius of contour corners, $\mathrm{m}$

$$
l_{a}=2 b-R+l_{n},
$$

where $l_{n}$ is the length of the roof-bolt part protruding from the blast-hole, which depends on its design and the bearing-supporting elements thickness, equal to $0.05-0.2 \mathrm{~m}$; radius of corner of arched parts of the mine face, i.e. small radius, $m$

$$
r=\frac{\left(a^{2}+c^{2}\right)^{0.5}-a+c}{2 \cos \psi}
$$

radius of corner of the central part of the mine face i.e. large radius, $\mathrm{m}$

$$
R=c+(a-r) \operatorname{tg} \theta
$$

where $\theta$ is the angle of normal stress action

$$
\theta=\frac{\pi}{2}-\psi
$$

where $\psi$ is the angle between the principal normal stress and the vertical plane, degree

$$
\operatorname{tg} \psi=\lambda .
$$

2. The density of the roof-bolts setting is determined from the $P_{m}-$ the perimeter of the mine working with an ellipsoidal shape, $\mathrm{m}$

$$
P_{m}=4 \frac{\pi a b+(a-b)^{2}}{a+b},
$$

where $V$ is the volume of massif, enclosed into the border energy zone, which is determined as the average value of the sums of differences between the vertical semi-axis of the zone $a$ and half of the mine working height $0.5 \mathrm{~h}$, and between the horizontal semi-axis of the zone $b$ and half of the mine working width $0.5 d, \mathrm{~m}$

$$
V=\frac{(a-0.5 h)+(b-0.5 d)}{2} .
$$

3. The distance between the roof-bolts, $\mathrm{m}$

$$
a=\sqrt{\frac{P_{a}}{U \gamma k_{o}}},
$$

where $P_{m}$ is the active perimeter of mine face, $\mathrm{m} ; \gamma$ is the bulk density of mine rocks within the area of possible destruction, $\mathrm{kN} / \mathrm{cu} . \mathrm{m} ; k_{o}$ is the roof-bolt overload coefficient; $P_{a}$ is the load-bearing capacity of the roof-bolt determined from the Table [23]. 


\begin{tabular}{|l|c|c|}
\hline \multicolumn{1}{|c|}{ Roof-bolt type } & $\begin{array}{c}\text { Compressive resistance of } \\
\text { rocks, MPa }\end{array}$ & $\begin{array}{c}\text { Load-bearing capacity of the } \\
\text { roof-bolt, } P_{a}, \mathrm{kN}\end{array}$ \\
\hline Reinforced-concrete & $>20$ & 100 \\
\hline Slot-and-wedge (joisting) & $60-100$ & $40-80$ \\
\hline Tubular (with expanding joist) & $>40$ & $60-120$ \\
\hline Resin-grouted & Any & $140-234$ \\
\hline Rope (ampoule) & & \\
\hline
\end{tabular}

After determination of key parameters, the support setting passports of preparatory mine working are developed in accordance to the computational scheme (Fig. 2).

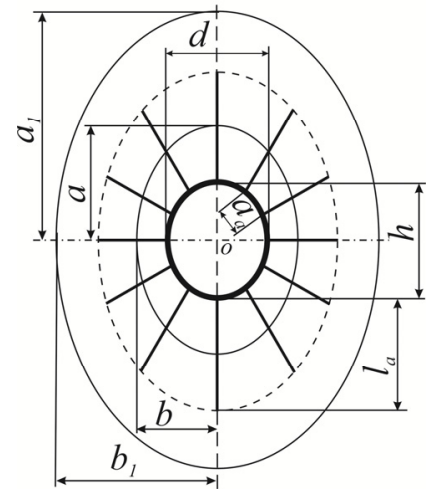

Fig. 2. The computational scheme to the drawing up of mine working support passport.

Since the actions of radial stresses are directed to the geometrical center of mine working, the drilling of blast-holes and, respectively, the roof-bolts setting are made from the center of mine working at the appropriate angles to the contour of massif outcrop [24, 25]. The mine working bottom is formed by means of ballast or concreting the lower part with laying in the center of drainage structure systems (flumes with covers, perforated pipes, shuttering). In order to avoid cleavage of small pieces of ore and rock during mine workings drivage in fractured rocks and ores, the combined support setting is used. For this purpose, the roof-bolts with Rabitz type steel-wire fabric, raised-perforated flooring, reinforced sheets etc., should be applied [26]. It is necessary to place the steel-wire fabric or other supporting structures along the mine working contour, in the roof and sides up to $80 \%$ of the fixed site length, and to fix with roof-bolts. In case, when the mine working intersects the ore and rocks strata, the roof-bolts should be set at an angle perpendicular to strata, which will lead to an increase in their length by $20-30 \%$ [27]. The required length of the roof-bolt set at an angle, perpendicular to strata, is the following, $\mathrm{m}$

$$
l_{y}=l_{a} \sin \alpha,
$$

where $\alpha$ is the angle of rocks strata or deposit dip, degree.

For support setting of prestressed rocks, it is reasonable the application of new generation roof-bolts, i.e. elongated roof-bolts with a joist location in the center of the energy imbalance. It allows to satisfy a condition of active resistance to massif destruction by using the elastic energy of the massif [28]. At the same time, the tensile energy of rocks is counterbalanced with energy of compression in the depth of the massif on outcrop of stope face or preparatory mine workings [29]. This makes possible to increase the rational depths of application of the roof-bolting and combined roof-bolting in preparatory mine workings, and also to exclude the application of expensive frame or concrete supports in 
preparatory mine workings $[30,31]$. At the same time, a basic element of such a support is the design of the roof-bolt and joists that are packed in the zone of active compression, but not just outside the area of rocks deformation [32]. The design and parameters of the separate elements of the self-regulating roof-bolt are represented in Fig. 3.

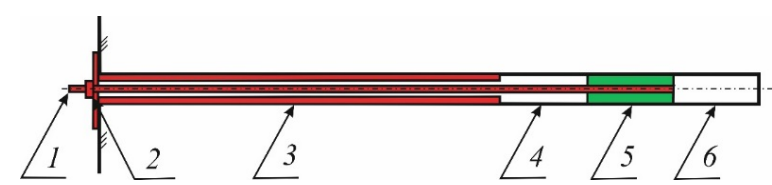

Fig. 3. Design of the self-regulating roof-bolt: 1 - roof-bolt (rope, polymer); 2 - hold-down strap and tightening nut; 3 - cased pipe; 4 - part of the blast-hole, free from casing; 5 - roof-bolt joist (concrete, wedge, chemical); 6 - free coal-face part of the blast-hole.

The length of cased pipe is determined for vertical and horizontal outcrops of the rocks massif and backfilling:

- roof-bolts set vertically, m

$$
l_{o v}=a-0.5 h+\frac{0.5 a_{n}}{3} ;
$$

- roof-bolts set horizontally, m

$$
l_{o h}=b-0.5 d+\frac{0.5 b_{n}}{3},
$$

where $a_{n}$ is the number of an energy imbalance zone, having the highest stiffness of elastic energy. As a rule, in the safety capsule this is the second zone from the mine working which size equals to $2 a$.

The length of a part of the blast-hole free from casing, the roof-bolt joist and free coalface part 6 are determined by an identical formula:

- roof-bolts set vertically, m

$$
l_{c v}=\frac{0.5 a_{n}}{3}
$$

- roof-bolts set horizontally, $\mathrm{m}$

$$
l_{c h}=\frac{0.5 b_{n}}{3} .
$$

The roof-bolt design (Fig. 3) allows the bolt to move inside the cased pipe by means of setting the joist in the zone of maximum contraction stresses directed backwards from the mine working. This design allows to counterbalance the maximum volume of energy consumed by the massif for destruction of a mine working contour by means of elastic energy resistance of the massif divergence [33].

\section{Results and discussion}

In accordance with the substantiated interrelation of a cross sectional shape of preparatory mine workings and the type of their support, represented in Table 1, it has been determined the cost of 1 long metre of mine working drivage (Table 2) [34]. The prime cost was determined by main types of expenses for mining-and-geological conditions of preparatory mine working drivage: cross-sectional area of preparatory mine working $S_{d r}=10.5$ sq.m ( $h=3 \mathrm{~m}, d=3.5 \mathrm{~m}$ ); depth of laying $H=1200 \mathrm{~m}$; strength of martite ores is $80 \mathrm{MPa}$; sizes 
of semi-axes of border and subsequent energy zones $a=3.98 \mathrm{~m}, a_{1}=7.96 \mathrm{~m}, a_{2}=11.93 \mathrm{~m}$, $a_{3}=15.92 \mathrm{~m}$ and $b=2.81 \mathrm{~m}, b_{1}=5.62 \mathrm{~m}, b_{2}=8.43 \mathrm{~m}, b_{3}=11.2 \mathrm{~m}$. Being the basic shapes of cross section in preparatory mine workings and types of their support setting, the accepted data have gained the greatest distribution in ore mines of Ukraine $[35,36]$ with the types of expenses and the prices operating since 2012 [37, 38].

Table 2. The prime cost of 1 long metre of preparatory mine working drivage depending on its cross sectional shape and support setting type.

\begin{tabular}{|c|c|c|c|c|c|c|}
\hline \multirow{2}{*}{$\begin{array}{c}\text { Laying depth } \\
\text { of mine } \\
\text { working, } \mathrm{m}\end{array}$} & \multicolumn{3}{|c|}{ Basic parameter } & \multicolumn{3}{|c|}{ Proposed parameter } \\
\hline & $\begin{array}{c}\text { cross section } \\
\text { shape }\end{array}$ & $\begin{array}{l}\text { applied } \\
\text { support }\end{array}$ & $\begin{array}{l}\text { prime cost, } \\
\mathrm{UAH} / \mathrm{m}\end{array}$ & $\begin{array}{c}\text { cross section } \\
\text { shape }\end{array}$ & $\begin{array}{l}\text { applied } \\
\text { support }\end{array}$ & $\begin{array}{c}\text { prime cost, } \\
\mathrm{UAH} / \mathrm{m}\end{array}$ \\
\hline 350 & \multirow{2}{*}{$\begin{array}{l}\text { trapezium- } \\
\text { shaped }\end{array}$} & \multirow{2}{*}{ wooden } & \multirow{2}{*}{4044.0} & circular & without support & 2643.0 \\
\hline 700 & & & & arched & shotcrete & 3164.0 \\
\hline 1000 & \multirow{3}{*}{ arched } & \begin{tabular}{|c|} 
reduced- \\
weight arched
\end{tabular} & 3882.0 & $\begin{array}{l}\text { crescent- } \\
\text { shaped }\end{array}$ & bolting & 3241.0 \\
\hline 1600 & & $\begin{array}{l}\text { improved } \\
\text { arched }\end{array}$ & 4624.0 & semielliptical & \multirow{2}{*}{$\begin{array}{c}\text { reduced-weight } \\
\text { combined }\end{array}$} & \multirow{2}{*}{3464.0} \\
\hline 3000 & & $\begin{array}{c}\text { monolithic } \\
\text { concrete }\end{array}$ & 5493.0 & elliptical & & \\
\hline
\end{tabular}

From Table 2 it can be seen that application of a stable shape of cross section and of the new support of mine working allows reducing the cost of its support setting. Thus, the laying of preparatory mine working with a stable shape allows to save by 1 long meter: at a depth up to $350 \mathrm{~m}-1401 \mathrm{UAH}$, up to $700 \mathrm{~m}-880 \mathrm{UAH}$, up to $1000 \mathrm{~m}-641 \mathrm{UAH}$, up to $1600 \mathrm{~m}-1160 \mathrm{UAH}$ and up to $3000 \mathrm{~m}-2029 \mathrm{UAH}$ [39]. There is a stable exponential dependence with an extremum point at a depth of $1000 \mathrm{~m}$, at which a sharp increase in saved costs begins on a support setting in the preparatory mine workings [40].

Then, the specific efficiency of preparatory operations has been determined, which depends on the massif energy used (Fig. 4).

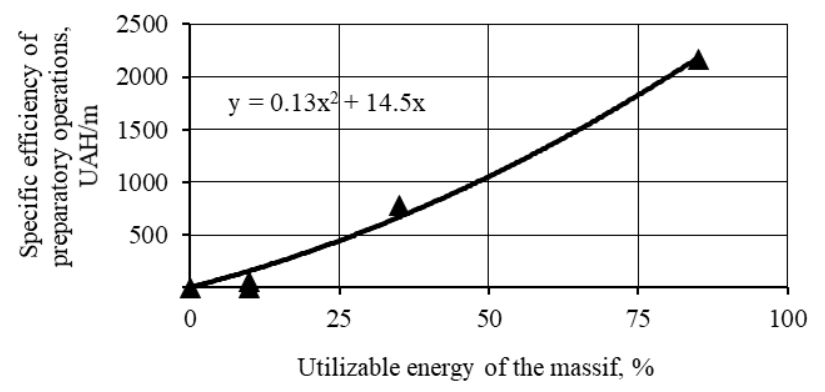

Fig. 4. The pattern of specific prime cost of preparatory operations with the massif energy use.

\section{Conclusions}

The energy of the safety capsule formed around the mine working is used according to the parabolic-and-hyperbolic dependence, the values on which correspond to the principles of resistance, equilibration, facilitating, elimination and transmission of concentrated energy of the massif. The support setting in mine workings with the designed principle of resistance is implemented with the energy costs equivalent to the energy of the massif $(100 \%)$. When using the principle of transmission, up to $86 \%$ of the massif energy can be used. 
The improvement of preparatory operations technology included giving the ellipsoidal contours both to the plane of the coal-face and to the cross section of preparatory mine workings of PJSC "Kryvorizkyi Iron-Ore Plant" (IOP) mines allows to counterbalance the stability of outcrops with the safety capsule in energy state without energy costs for maintenance. And the additional application of self-regulating roof-bolting which works by the principle of transmission of convergence energy, destroying the outcrop contour, into the zone with active divergence, and allows to use the maximum amount of the energy generated in the safety capsule of the mine working with the resources saving up to $37 \%$.

The efficiency assessment of the developed resource-saving technologies implementation for mine workings support setting in Ukrainian ore mines is based on the method of local and general prime cost determination during ore deposits mining. The use of up to $86 \%$ of the relative amount of the energy concentrated in the massif around preparatory mine workings increases by exponential function the specific economic efficiency of preparatory operations. It allows to reduce the expenses up to 2029 UAH per 1 long meter during mine workings drivage with application of the self-regulating roofbolting in mines of PJSC "Kryvorizkyi IOP”.

The authors express their gratitude to Usatyi V.Yu., the production director of PJSC "Zaporizkyi IOP", Rychko V.S., the technical director of PJSC "Kryvorizkyi IOP", Pukhalskyi V.N., the chief engineer of SE 'Shidnyi Mining and Beneficiation Plant' for assistance in providing production data and implementation of the received results.

\section{References}

1. Shemyakin, E.I., Kurlenya, M.V., Oparin, V.N., Reva, V.N., Glushikhin, F.P., \& Rozenbaum, M.A. (1992). Yavlenie zonal'noy dezintegratsii gornykh porod vokrug podzemnykh vyrabotok. Otkrytie No. 400, SSSR.

2. Kirichenko, V.Ya., Zvyagi'skiy, E.L., Lishin, A.V., Usachenko, B.M., \& Khalimendik, Yu.M. (2002). Yavlenie obrazovaniya peremeshchayushchikhsya narushennykh zon $v$ napryazhennykh gornykh porodakh. Otkrytie No. 188. Ukraine.

3. Baysarov, L.V., Il'yashov, M.A., Levit, V.V., Palamarchuk, T.A., Usachenko, V.B., \& Yalanskiy, A.A. (2008). Zakonomernost' samoorganizatsii gruntovykh $i$ porodnykh massivov vokrug protyazhennykh podzemnykh vyrabotok. Otkrytie No. 318. Ukraine.

4. Khomenko, O. (2012). Implementation of energy method in study of zonal disintegration of rocks. Naukovyi Visnyk Natsionalnoho Hirnychoho Universytetu, (4), 44-54.

5. Khomenko, O., Kononenko, M., \& Bilegsaikhan, J., (2018). Classification of Theories About Rock Pressure. Solid State Phenomena, (277), 157-167. https://doi.org/10.4028/www.scientific.net/ssp.277.157

6. Kononenko, M., Khomenko, O., Sudakov, A., Drobot, S., \& Lkhgva, Ts. (2016). Numerical modelling of massif zonal structuring around underground working. Mining of Mineral Deposits, 10(3), 101-106. http://dx.doi.org/10.15407/mining10.03.101

7. Sobolev, V., Ustimenko, Y., Nalisko, M., \& Kovalenko, I. (2018). The macrokinetics parameters of the hydrocarbons combustion in the numerical calculation of accidental explosions in mines. Naukovyi Visnyk Natsionalnoho Hirnychoho Universytetu, (1), 89-98. https://doi.org/10.29202/nvngu/2018-1/8

8. Stupnik, N., Kalinichenko, V., \& Pismennyi S. (2013). Pillars sizing at magnetite quartzites roomwork. Mining Of Mineral Deposits, 11-15. https://doi.org/10.1201/b16354-4

9. Soboliev, V.V., Bilan, N.V., \& Khalimendik, A.V. (2017). On formation of electrically conductive phases under electrothermal activation of ferruginous carbonate. Naukovyi Visnyk Natsionalnoho Hirnychoho Universytetu, (4), 53-60.

10. Lozynskyi, V., Saik, P., Petlovanyi, M., Sai, K., \& Malanchyk, Ye. (2018). Analytical Research of the Stress-Deformed State in the Rock Massif Around Faulting. International Journal of 


$\begin{array}{lclll}\begin{array}{l}\text { Engineering } \\ \text { https://doi.org/10.4028/www.scientific.net/JERA.35.77 }\end{array} & \text { Africa, } & \text { (35), } & \text { 77-88. }\end{array}$

11. Dychkovskyi, R.O., Lozynskyi, V.H., Saik, P.B., Petlovanyi, M.V., Malanchuk, Ye.Z., \& Malanchuk, Z.R. (2018). Modeling of the disjunctive geological fault influence on the exploitation wells stability during underground coal gasification. Archives of Civil and Mechanical Engineering, 18(4), 1183-1197. https://doi.org/10.1016/j.acme.2018.01.012

12. Khomenko, O.Ye., Sudakov, A.K., Malanchuk, Z.R., \& Malanchuk, Ye.Z. (2017). Principles of rock pressure energy usage during underground mining of deposits. Naukovyi Visnyk Natsionalnoho Hirnychoho Universytetu, (2), 35-43.

13. Gorova, A., Pavlychenko, A., Borysovs'ka, O., \& Krups'ka, L. (2013). The development of methodology for assessment of environmental risk degree in mining regions. Annual ScientificTechnical Collection - Mining of Mineral Deposits, 207-209. https://doi.org/10.1201/b16354-38

14. Astafiev, D., \& Shapovalov, Y. (2013). On the question of implementation prospects of selective mining for exploitation unconditional coal seams. Annual Scientific-Technical Collection Mining of Mineral Deposits, 313-316. https://doi.org/10.1201/b16354-58

15. Babets, D., Sdvyzhkova, O., Larionov, M., \& Tereshchuk, R. (2017). Estimation of rock mass stability based on probability approach and rating systems. Naukovyi Visnyk Natsionalnoho Hirnychoho Universytetu, (2), 58-64.

16. Khomenko, O., \& Maltsev, D. (2013). Laboratory research of influence of face area dimensions on the state of uranium ore layers being broken. Naukovyi Visnyk Natsionalnoho Hirnychoho Universytetu, (2), 31-37.

17. Stupnik, N.I., Kalinichenko, V.A., Kolosov, V.A., Pismenniy, S.V., \& Fedko, M.B. (2014). Testing complex-structural magnetite quartzite deposits chamber system design theme. Metallurgical and mining industry, (2), 89-93.

18. Bondarenko, V., Symanovych, G., \& Koval, O. (2012). The mechanism of over-coal thin-layered massif deformation of weak rocks in a longwall. Geomechanical Processes During Underground Mining: School of Underground Mining 2012, 41-44. https://doi.org/10.1201/b13157-8

19. Vladyko, O., Kononenko, M., \& Khomenko, O. (2012). Imitating modeling stability of mine workings. Geomechanical Processes During Underground Mining, 147-150. https://doi.org/10.1201/b13157-26

20. Kononenko, M., \& Khomenko, O. (2010). Technology of support of workings near to extraction chambers. New Techniques And Technologies In Mining, 193-197. https://doi.org/10.1201/b11329-32

21. Khomenko, O., Kononenko, M., \& Myronova, I. (2013). Blasting works technology to decrease an emission of harmful matters into the mine atmosphere. Annual Scientific-Technical Collection - Mining of Mineral Deposits, 231-235. https://doi.org/10.1201/b16354-43

22. Khomenko, O., Sudakov, A., Malanchuk, Z., \& Malanchuk, Ye. (2017). Principles of rock pressure energy usage during underground mining of deposits. Naukovyi Visnyk Natsionalnoho Hirnychoho Universytetu, (2), 35-43.

23. Belmas, I., Kolosov, D., \& Onyshchenko, S. (2018). Stress-strain state of rubber-cable tractive element of tubular shape. Naukovyi Visnyk Natsionalnoho Hirnychoho Universytetu, (2), 60-69. https://doi.org/10.29202/nvngu/2018-2/5

24. Dreus, A.J., Sudakov, A.K., \& Kozhevnikov, A.A. (2016). Investigation of heating of the drilling bits and definition of the energy efficient drilling modes. Eastern-European Journal of Enterprise Technologies. Technologies, 3(7(81)), 41-46. https://doi.org/10.15587/1729-4061.2016.71995

25. Kolosov, D., Dolgov, O., \& Kolosov, A. (2013). The stress-strain state of the belt on a drum under compression by flat plates. Annual Scientific-Technical Collection - Mining of Mineral Deposits, 351-357. https://doi.org/10.1201/b16354-65

26. Khomenko, O., Kononenko, M., \& Myronova, I. (2017). Ecological and technological aspects of iron-ore underground mining. Mining of Mineral Deposits, 11(2), 59-67. https://doi.org/10.15407/mining11.02.059 
27. Dreus, A., Kozhevnikov, A., Lysenko, K., \& Sudakov, A. (2016). Investigation of heating of the drilling bits and definition of the energy efficient drilling modes. Eastern-European Journal of Enterprise Technologies, 3(7(81), 41-46. https://doi.org/10.15587/1729-4061.2016.71995

28. Dreus A.Yu., Sudakov, A.K., Kozhevnikov, A.A., \& Vakhalin, Yu.N. (2016). Study on thermal strength reduction of rock formation in the diamond core drilling process using pulse flushing mode. Naukovyi Visnyk Natsionalnoho Hirnychoho Universytetu, (3), 5-10.

29. Sudakov, A., Dreus, A., Khomenko, O., \& Sudakova, D. (2017). Analytical study of heat transfer in absorptive horizons of borehole at forming cryogenic protecting of the plugging material. Naukovyi Visnyk Natsionalnoho Hirnychoho Universytetu, (3), 38-42.

30. Khomenko, O., Kononenko, M., Myronova, I., Sudakov, A. (2018). Increasing ecological safety during underground mining of iron-ore deposits deposits. Naukovyi Visnyk Natsionalnoho Hirnychoho Universytetu, (2), 29-38. https://doi.org/10.29202/nvngu/2018-2/3

31. Bondarenko, V., Kovalevs'ka, I., \& Fomychov, V. (2012). Features of carrying out experiment using finite-element methodat multivariate calculation of mine massif - combined support system. Geomechanical Processes During Underground Mining, 7-13. https://doi.org/10.1201/b13157-3

32. Kozhevnykov, A., Dreus, A., Baochang, L., \& Sudakov, A. (2018). Drilling fluid circulation rate influence on the contact temperature during borehole drilling. Naukovyi Visnyk Natsionalnoho Hirnychoho Universytetu, (1), 35-42. https://doi.org/10.29202/nvngu/2018-1/14

33. Sudakov, A. Khomenko, O., Isakova, M., \& Sudakova, D. (2016). Concept of numerical experimentof isolation of absorptive horizons by thermoplastic materials. Naukovyi Visnyk Natsionalnoho Hirnychoho Universytetu, (5), 12-16.

34. Fedko, M.B., Kolosov, V.A., Pismennyi, S.V., \& Kalinichenko, Ye.V. (2014). Economic aspects of change-over to TNT-free explosives for the purposes of ore underground mining in Kryvyi Rih basin. Naukovyi Visnyk Natsionalnoho Hirnychoho Universytetu, (4), 79-84.

35. Khomenko, O., \& Rudakov, D. (2010). The first Ukrainian corporative university. New Techniques and Technologies in Mining, 203-206. https://doi.org/10.1201/b11329-34

36. Gorova, A., Pavlychenko, A., Kulyna, S., \& Shkremetko, O. (2012). Ecological problems of postindustrial mining areas. Geomechanical Processes During Underground Mining, 35-40. https://doi.org/10.1201/b13157-7

37. Stupnik, N.I., Fedko, M.B. Pismenniy, S.V., \& Kolosov, V.A. (2014). Development of recommendations for choosing excavation support types and junctions for uranium mines of stateowned enterprise "SkhidHZK". Naukovyi Visnyk Natsionalnoho Hirnychoho Universytetu, (5), 21-25.

38. Khomenko, O., Tsendjav, L., Kononenko, M., \& Janchiv, B. (2017). Nuclear-and-fuel power industry of Ukraine: production, science, education. Mining of Mineral Deposits, 11(4), 86-95. https://doi.org/10.15407/mining11.04.086

39. Fuławka, K., Mertuszka, P., \& Pytel, W. (2018). Monitoring of the stability of underground workings in Polish copper mines conditions. E3S Web Of Conferences, (29), 00008. https://doi.org/10.1051/e3sconf/20182900008

40. Pivnyak, G., Dychkovskyi, R., Smirnov, A., \& Cherednichenko, Y. (2013). Some aspects on the software simulation implementation in thin coal seams mining. Energy Efficiency Improvement of Geotechnical Systems, 1-10. https://doi.org/10.1201/b16355-2 